\title{
FAMILY CONTROL AND EARNINGS MANAGEMENT IN BRAZILIAN LISTED COMPANIES: A RELATIONSHIP MEDIATED BY AGE
}

\section{CONTROLE FAMILIAR E GERENCIAMENTO DE RESULTADO EM EMPRESAS BRASILEIRAS LISTADAS: UMA RELAÇÃO MEDIADA PELA IDADE}

\section{CONTROL FAMILIAR Y GERENCIAMENTO DE RESULTADO EN EMPRESAS BRASILEÑAS LISTADAS: UNA RELACIÓN MEDIADA POR LA EDAD}

Recebido em: 23/08/2018

Avaliado em: 13/03/2019

Reformulado em: 28/03/2019

Aceito para publicação em: 24/05/2019

Publicado em: 03/07/2019

Editor Responsável: Moacir M. Rodrigues Junior

\author{
Roberto Tommasetti ${ }^{1}$ \\ Marcelo Álvaro da Silva Macedo ${ }^{2}$ \\ Fabrícia de Farias da Silva Constantino ${ }^{3}$ \\ Alfredo Sarlo Neto ${ }^{4}$
}

\begin{abstract}
A family-owned company potentially represents the realm of the agency theory because, if on one side this kind of organization shows lower Type I agency conflicts due to the proximity between ownership and management, on the other side it emphasizes Type II conflicts, within ownership, between majority and minority shareholders. In this situation, the literature suggests a positive and a negative impact of the family control on earnings quality, named alignment and entrenchment effect respectively. The socioemotional wealth (SEW) theory also associates the presence of the familyowner to debatable consequences, since SEW preservation attitude can affect the business decisionmaking process, especially in the first phase of family firm's life where family objectives have priority over business objectives. The present study aims to investigate the influence of the family control in the quality of earnings, answering the following research questions: (i) do family firms engage less in earnings management than non-family firms? (ii) does the relation between family ownership and earnings management differ between younger and older family firms? The main finding is that old family firms engage less than any other group subsample in earning management practices, questioning literature that mainly considers family firms to be a homogeneous category.
\end{abstract}

Key-words: Family control, Young and Old Family Firms, Accounting Earnings Management, Agency Theory, Socio-Emotional Wealth Theory

\footnotetext{
${ }^{1}$ Doutor em Ciências Contábeis pela Universidade Federal do Rio de Janeiro; Professor do Departamento de Ciências Contábeis da Universidade Federal do Rio de Janeiro; E-mail: roberto.tommasetti@ufrj.br

${ }^{2}$ Doutorado em Engenharia de Produção pela Universidade Federal do Rio de Janeiro; Professor dos Programas de PósGraduação em Ciências Contabeis da Universidade Federal do Rio de Janeiro e de Contabilidade da Universidade Federal do Espírito Santo; E-mail: malvaro.facc.ufrj@gmail.com

${ }^{3}$ Doutoranda em Ciências Contábeis pela Universidade Federal do Rio de Janeiro; Professora da Universidade Federal Rural do Rio de Janeiro; E-mail: fabriciadefarias@gmail.com

${ }^{4}$ Doutor em Controladoria e Contabilidade pela Universidade de São Paulo; Professor dos Programas de Pós-Graduação em Contabilidade da Universidade Federal do Espírito Santo e de Ciências Contabeis da Universidade Federal do Rio de Janeiro; E-mail: supersarloneto@gmail.com
} 


\section{RESUMO}

A empresa familiar potencialmente representa o reinado da Teoria da Agência porque, se por um lado mostra menores conflitos de agência do Tipo I devido à maior proximidade entre a propriedade $\mathrm{e}$ administração, por outro acentua conflitos do Tipo II entre o grupo familiar de controle e os sócios minoritários. Nessa situação, a literatura acadêmica sugere a existência de um impacto positivo e outro negativo do controle familiar sobre a qualidade da informação financeira, denominados, respectivamente, de efeito-alinhamento e efeito-entrincheiramento. A Teoria da Riqueza Socio Emocional (RSE) também associa a presença da propriedade familiar à consequências discutíveis, já que a atitude de preservação da RSE pode afetar o processo de tomada de decisão do negócio, em especial na primeira fase de vida da empresa familiar, onde os objetivos da família têm prioridade sobre os objetivos do negócio. O presente estudo objetiva investigar a influência do controle familiar na qualidade dos lucros, respondendo as seguintes questões de pesquisa: (i) empresas familiares se engajam menos em práticas de gerenciamento de resultados que empresas não familiares? (ii) a relação entre controle familiar e gerenciamento de resultado difere entre empresas familiares jovens e antigas? O principal achado é que empresas familiares antigas se engajam menos que qualquer outro dos grupos subamostrados em práticas de gerenciamento de resultados, desafiando a literatura que considera empresas familiares como uma categoria homogênea.

Palavras-Chave: Controle Familiar; Empresas Familiares Jovens e Antigas; Gerenciamento de Resultados Contábeis; Teoria da Agência; Teoria da Riqueza Socio Emocional.

\section{RESUMEN}

La empresa familiar potencialmente representa el reino de la teoría de agencia porque, si por un lado muestra menores conflictos de Tipo I debido a la proximidad entre propiedad y administración, en el otro lado enfatiza conflictos de Tipo II, dentro de la propiedad, entre la mayoría y los accionistas minoritarios. En esta situación, la literatura sugiere un impacto positivo y negativo del control familiar sobre la calidad de la información contable, denominados respectivamente efecto de alineamiento y atrincheramiento. La teoría de la riqueza socioemocional también asocia la presencia del propietario familiar con consecuencias discutibles, especialmente en la primera fase de la vida de la empresa cuando los objetivos familiares tienen prioridad sobre los comerciales. El objetivo del presente estudio es investigar la influencia del control familiar en la calidad de la información contable, respondiendo las siguientes preguntas: (i) ¿Las empresas familiares se involucran menos en prácticas de gerenciamiento de resultado que las empresas non familiares? (ii) ¿La relación entre la propiedad familiar y el gerenciamiento de resultado difiere entre las empresas familiares más jóvenes y las más viejas? El hallazgo principal es que las empresas familiares antiguas participan menos que cualquier otra submuestra grupal en prácticas de gerenciamiento de resultado, cuestionando la literatura que considera empresas familiares como una categoría homogénea.

Palabras clave: Control Familiar, Empresas Familiares Jóvenes y Viejas, Gerenciamientos Contables de Resultado, Teoría de la Agencia, Teoría de la Riqueza Socioemocional

\section{INTRODUCTION}

Family business is important for economic growth and of great interest to researchers. It is estimated that it accounts for more than half of the world GDP and, therefore, related studies are relevant because it is an emerging focus with a considerable impact (Chrisman, Chua, \& Kellermanns, 2009).

At the same time, high-quality financial reporting is well appreciated by the market as it reduces information asymmetries, increases overall transparency, and provides a better device for contracting purposes. Consequently, financial reporting of higher quality is associated with lower 
cost of equity and debt (Francis et al., 2005), higher market liquidity (Diamond, \& Verrecchia, 1991), better firm performance, and higher competitiveness.

Salvato and Moores (2010) conducted a bibliometric study on accounting issue and family firms, finding that earnings quality and (accounting vs real) earnings management strategies and incentives are the most frequent.

This is due to the very peculiar corporate governance environment that is naturally developed in a family run business along generations. This type of organization potentially represents the realm of the agency theory (WANG, 2006) because, if on one side it shows lower Type I agency conflicts due to the proximity between ownership and management (Prencipe, \& Bar-Yosef, 2011), on the other side it emphasizes Type II conflicts, within ownership, between majority and minority shareholders (Fama, \& Jensen, 1983). In this situation, the literature suggests a negative and a positive impact of the family control at the same time on earnings quality, named respectively entrenchment and alignment effect.

Family-run companies are considered less transparent because of the excessive power of the majority shareholder not adequately counterbalanced by an independent internal control system. This common sense is confirmed by empirical evidence showing that higher information asymmetries generate higher incentives to bad quality financial reporting (Fan, \& Wong, 2002; Francis et al., 2005), causing an entrenchment effect in concentrated ownership structures.

These findings are based on the view of family control being a less efficient ownership structure because family behaviours can be more easily aimed at extracting private benefits from the companies they control, at the expenses of minority shareholders, who suffer asymmetric information and ineffective control systems (Fama, \& Jensen 1983; Shleifer, \& Vishny, 1986; Morck, Shleifer, \& Vishny, 1988).

At the same time, family-run companies benefit from the natural alignment between management and the interests of shareholders in the common goal of creating long-term value to preserve the family's reputation and, consequently, the company's continuity along generations (Setia-Atmaja, Tanewski, \& Skully, 2009). In other terms, families have higher incentives to report good quality earnings because they need to preserve the family's (sur)name since they need to pass on their business to future generations and they, therefore, look for long-term profitability.

According to this view, family ownership generates more effective monitoring by controlling owners: families are interested in a good quality reporting and higher earning quality to preserve family's reputation, generating an alignment effect (Wang, 2006). In family-run business management and shareholders' interests naturally share the common purpose of creating value in the long run to preserve the survival of the firm from generation to generation. Even if a non-familymember is acting as CEO, studies demonstrate that management monitoring by family controlling shareholders is much more effective than in a large public company without block holders (Demsetz, \& Lehn, 1985; Shleifer, \& Vishny, 1986).

After investigating the relationship between family ownership and earnings management, we study if it is linear or if it differs between younger and older family firms. The socioemotional theory predicts that the (socioemotional) wealth is strongest in the founding-family-controlled stage (this is younger family firms) and lower in later generational stages. Family firms in later generational stages attach less weight to preserving socioemotional wealth and thus have less incentive to engage in earnings management than firms in the controlling owner stage, which - under the agency theory framework - should suffer a non-dilution entrenchment effect.

Authors expect that family firms are less engaged than non-family firms in earnings management practices and that, within family firms, older are more propense for higher earnings quality.

This work contributes to the literature with a deeper understanding of family business and its inference with earnings quality, because there are still few studies in this important segment of the 
national economy and, as far as the authors' knowledge, none of them analyses the age mediation role.

The study also contributes to the debate of family firm heterogeneity. Although studies have acknowledged that family firms are a heterogeneous group (Sharma, 2004), up until now research on earnings management in public family firms has mainly considered family firms to be a homogeneous group. On the contrary, results suggest that the generational stage has a significant influence on the level of earnings management.

Furthermore, findings also fuel the debate on risk behaviour in family firms. The family firms' literature often portrays family firms as having a long-term vision or patient capital while we demonstrated that in terms of accounting earnings management, their approach became virtuous just with the passage of time. The paper is organized as follows: in chapter 2 the literature review on the argument is offered with research hypothesis' formulation; in chapter 3, the methodology is explained to identify the dependent, the independent and control variables together with the regression models to validate the hypothesis on the field. Finally, results and conclusions are presented, respectively, in chapter 4 and 5 .

\section{LITERATURE REVIEW}

In the following chapter, we illustrate the relevant literature related to the relationship between family firms and earnings quality (2.1) along the family presence life cycle (2.2).

\subsection{Family Firms and Earnings Quality}

Literature provides different definitions of family firms which mainly belong to two dominant theoretical approaches: the components-of-involvement and the essence approach.

According to the former, family involvement is enough for a business to be classified as family business: in other terms, it is sufficient condition that some kind of family involvement exists, such as ownership, management, or governance to be considered as a family firm (Chrisman, Chua, \& Sharma, 2005). According to the essence approach, family involvement is only a necessary condition. Other additional elements are required to characterize business as a family business, such as intention, vision, familiness. Therefore, the essence approach requires that family involvement must be directed towards behaviours that provide distinctiveness for a company to be considered a family firm. All these elements contribute to creating the peculiar and unique resources through the combination of family and business systems, hard to duplicate.

Independent of the criteria, family firms represent one-third of the S\&P 500 companies and Fortune 500 companies. It is estimated that these companies account for $85 \%$ of all companies worldwide, $65 \%$ of the GDP and employment in Europe, and 50\% of the GDP of the US and 60\% of its employment (Barroso et al., 2018). More than two-thirds of listed firms in East Asian countries, including Taiwan, are controlled by founding families or individuals (Chu, 2011). Further, familycontrolled firms dominate most developing economies in South America. Moreira Júnior and Bortoli Neto (2007) emphasize that in Brazil, family-run companies can reach 95\% of the businesses, with a predominance in some sectors (services, agribusiness, and commerce).

But, although listed family firms represent a relatively significant part of the corporate sector in many developed and developing countries, there is still little empirical study about them (Filatotchev, Lien, \& Piesse, 2005).

As to quality earnings, scholars point out that family ownership could affect the supply of earnings quality in two competing ways: the entrenchment effect and the alignment effect.

According to the former, concentrated ownership incentivizes control shareholders to expropriate wealth from other shareholders (Morck, Shleifer, \& Vishny, 1988). Fama and Jensen (1983) showed that large undiversified shareholders, such as family members, managers, and 
individuals closely related to the firm would entrench their investment decisions relative to minority shareholders, as the ownership of stocks (therefore, voting rights) is concentrated in one major group of shareholders. These major shareholders would have access to exclusive privileged information, which leads towards an information gap with minority shareholders. In other terms, large shareholders might be tempted to use their controlling position to obtain personal benefits at their expense.

Family members are often involved in both the management team and the board of directors; therefore, they can exploit the information asymmetries to their advantage.

Demsetz and Lehn (1985) suggest that concentrated major shareholders might choose nonpecuniary consumption and therefore take scarce resources away from profitable projects. Consequently, the combination of ownership and control could allow major shareholders to exchange profits for private rents (Fama, \& Jensen, 1983).

Fan and Wong (2002) highlight that family ownership is associated with lower earnings quality because of greater agency conflicts and information asymmetry in seven countries of East Asia, where the legal protection of minority shareholders is weaker and financial reporting is less transparent. According to the authors, the close relationship between family members and managers may "suggest" managers to manage earnings towards the goals of the controlling family at the expense of minority shareholders wealth.

Firth, Fung and Rui (2007) find that Chinese firms with highly concentrated share ownership show lower earnings informativeness because of an entrenchment effect, whereas companies with foreign shareholders and the higher percentage of tradable shares appear to enhance earnings quality.

In Norway literature, Abdolmohammadi, Kvaal and Langli (2010) find evidence of earnings management tendencies of private family firms.

On the other hand, according to the alignment hypothesis, family ownership is positively related to financial reporting quality, as the reduction of Type I agency conflicts between owners and managers reduce managers' incentives to report accounting information that deviates from underlying economic performance.

With some exceptions, supporting evidence of this theory are usually reported by studies based on evidence from contexts, such as the United States and the United Kingdom.

The US-based studies of Jiraporn and Dadalt (2009) and Wang (2006) and Prencipe and BarYosef (2011) for Italy provide empirical evidence that the level of abnormal accruals is lower for family firms than for their non-family counterparts. These findings suggest that the family long-tenure in the company forces itself to focus primarily on the long run objectives, limiting the management willingness to meet short-term earnings expectations, and provides firm-specific knowledge, enabling the (family) shareholder to better monitoring management.

Villalonga and Amit (2006) point out that ownership concentration should have a positive effect on firm's value because the presence of block holders would alleviate the conflict of interests between the principal and the agent, suggesting the latter to provide high-quality earnings in accordance with former's expectations.

Tiscini and Di Donato (2008) investigate the impact of family control and corporate governance practices on earnings quality of listed Italian firms, finding that the presence of a family $\mathrm{CEO}$ has a positive effect on earnings quality, confirming the alignment effect. The underlying theory is that if the family is highly involved in the management and (or) in the governance of the company, it will be more willing to protect its reputation through careful monitoring of management, because of its long-term investment horizon and lower incentives to short-term earnings management.

Given that the family is concerned about the longevity of the firm, family firms are presumed to be less subject to managerial myopia and more inclined to invest into positive NPV projects rather than boost current earnings by engaging in risky projects. The long-term investment horizon of family shareholders reduces the capital market pressure to meet short-term earnings targets such as analyst or management forecasts (Graham, Harvey, \& Rajgopal, 2005).

Chen, Chen, and Cheng (2008) report that family-controlled S\&P 1500 firms provide more 
earnings warnings, consistent with family owners being more concerned with the litigation-related and reputation costs of withholding bad news.

Similar results are reported by Warfield, Wild and Wild (1995) and by Wang (2006), who reports lower abnormal accruals, greater earnings informativeness, and lower persistence of transitory components for the family company within S\&P 500 firms.

Jung and Kwon (2002) and Cascino et al. (2010) also found support for the alignment hypothesis in Korean and Italian family firms, respectively, finding that the convergence of interest of the owner-manager structure increases the earnings informativeness.

Yeo et al. (2002) find that, on a sample of firms listed on the Singapore stock exchange, the earnings informativeness has a positive relationship with ownership management, confirming by the alignment hypothesis.

As to Brazil, Torres et al. (2010) demonstrate that concentrated ownership should promote artificial earnings smoothing practices. More specifically, Fasolin and Klann (2015) show that family firms increased earning management practices after IFRS implementation. Silva et al. (2016) analyse how family control impacts the quality of accounting information of non-financial listed companies in Brazil, focusing on the value relevance for the period 2010-2012. Results demonstrate that family control has a positive impact on the quality of accounting information, showing overlapping alignment effect on the entrenchment effect.

In line with the alignment assumption, this paper aims to contribute to the recently increasing stream of literature on the economic efficiency of listed family firms, under the perspective of information asymmetries and transparency, formulating the Hypothesis 1: Family firms engage less in earnings management practices than non-family-controlled firms.

\subsection{The Generational Stage}

After investigating the relationship between family ownership and earnings management, we study if it is linear or if it differs between younger and older family firms.

Anderson and Reeb (2003) have studied the impact of the family firms age on performance. Differentiating between young and old family firms (firm age greater than 50 years), they find that both groups exhibit better firm performance relative to non-family firms. Leite and Caravalhal (2016) demonstrate that the relationship is not shaped as an inverted $U$ in Brazil, and that older firms show higher value and better return on their investments. Authors also report that older firms show better governance practices.

But, as far as the authors' knowledge, none has studied the impact of this variable on the earnings quality. Wang (2006) investigates the relationship between founding family ownership (this variable depending on the involvement of the founding family in the company's governance), finding an un-explicated positive impact of the control variable age on earnings quality. The reason can be found under both SEW and Agency Theory frameworks.

First, the socioemotional theory posits that the (socioemotional) wealth is strongest in the founding-family-controlled stage (this is younger family firms) and lower in later generational stages (Gavana, Gottardo, \& Moisello, 2017). Research that has examined goal variation in family firms suggests that the importance of non-financial goals is closely associated with the generation in charge of the firm. Westhead (2003) finds that first generation firms are significantly more likely than multigenerational firms to report that family objectives have priority over business objectives. Van Gils, Voordeckers, and Van den Heuvel (2004) find that when the second or third generations take over the management and (or) ownership of the firm, the independence objectives become less important. Gómez-Mejía et al. (2007) find that the willingness to relinquish family control is lowest in earlier generational stages when socioemotional wealth is highest. These observations suggest that when successive generations enter the firm, the focus shifts from family objectives to a combination of family and business objectives. 
As more and more generations are involved in the business, family ties become weaker, and each family branch will place the needs of its nuclear household first (Ensley, \& Pearson, 2005; Gersick, 1997). Furthermore, as the number of generations increases, so does the risk of intrafamily conflict (Ensley, \& Pearson, 2005; Schulze, Lubatkin, \& Dino, 2002). In sum, each family branch has different needs, agendas, capabilities, and commitments, making it difficult for a family to maintain a shared vision. Consequently, more formal governance mechanisms tend to be necessary to manage the interests of these different family branches (Jaffe, \& Lane, 2004). For example, the inclusion of independent directors that can act as arbitrators in family conflicts might be necessary (Voordeckers, Van Gils, \& Van Den Heuvel, 2007). And if independent boards are installed, then both family and business interests are protected. Hence, the likelihood that family firms focus mainly on family objectives reduces.

Many studies show that age is positively related to good practices of governance. Ariff, Ibrahim and Othman (2007) make a comparative study about variables related to governance reporting of firms in Malaysia, finding a firm age as positively related to governance. Firms with a history of good reputation and experience have greater skills to separate good and bad governance practices.

Finally, in multigenerational firms, ownership is likely to be dispersed, including a growing amount of passive family members (Jaffe, \& Lane, 2004). These passive family members tend to be less overinvested in the family firm so that their risk preferences are like those of outside investors in public firms (Schulze, Lubatkin, \& Dino, 2002). Hence, these family members are expected to behave more as diversified investors and will, therefore, dedicate more attention to business objectives. All these arguments suggest that the attachment of the family to the organization and the family's social capital tend to weaken across subsequent generations (Gómez-Mejía et al., 2007). Consequently, family firms in later generational stages attach less weight to preserving socioemotional wealth and thus have less incentive to engage in upward earnings management than firms in the controlling owner stage. Following this theory, in a sample of private Flemish firms, Stockmans, Lybaert and Voordeckers (2010) show that both second- and third- and later generation family firms perform less upward earnings management than do first-generation family firms.

The need for higher earnings quality in older family firms could be reconducted within the agency theory. Keasey, Martinez and Pindado (2015) study the relationship between leverage and a firm's willingness to dilute control, moderated by ownership type (family vs non-family) and business lifecycle stage, in a panel data from 16 European countries for the period 2000-2009. The result is that the relationship between leverage and the main shareholder's stake is positive. Specifically, larger stakes in the firm are associated with more involvement and a greater attachment to the business, and less willingness to dilute control. This is known as the non-dilution entrenchment effect and leads the firm to issue more debt, a financing source with less loss of control for listed firms. This is stronger in the younger family firm. Family firms are a special type of firm, more tied to the business (thus more averse to control risk) and more able to issue debt at lower costs given their undiversified portfolios and reputation. These two reasons lead them to increase their aversion to dilute control and to strengthen the effect of ownership on leverage. Also, young family firms are typically characterized by the presence of the founder, who may be reluctant to dilute family control given their long-term perspective. However, as a family firm grows older, more succession conflicts arise, and the dilution of the family stake can be needed.

Authors' expectation is that older family firms are less exposed to this non-dilution entrenchment effect and they need to provide higher quality information to be attractive for outsidefamily investors. Therefore, we postulate Hypothesis 2: Older family firms engage less in earnings management practices than young family firms. 


\section{RESEARCH DESIGN}

The research can be considered as a quantitative study based on secondary data. The population is composed by Brazilian active firms issuing common stock listed at B3 main market. Accounting, financial and (some) corporate governance data are collected from the same database, S\&P's Capital IQ, in December 2017. Corporate governance data are complemented by information in EconoInfo website and from the companies' latest published Reference Form (Formulário de Referencia, RF).

As far as to the period, it starts from 2012, since the IFRSs were fully introduced in Brazil from 2011 and some variables are calculated as a difference with previous period, and it ends in 2016, the most recent available closed year.

From initial data sample, we remove (i) financial institutions due to their peculiar accounting standards and regulatory status, (ii) companies incorporated or listed after 2011 or (iii) delisted due to mergers, acquisitions, or bankruptcy after 2011 and (iv) firms with missing or inconsistent data during the period. Finally, we get a final balanced panel of 151 listed in Brazil for a total of 755 firmyear observations along the period.Pre-requisite, common to both hypotheses to be tested, is the definition of the family control dummy. The greater portion of studies on this topic mainly discriminates between family and non-family firms by looking at the degree of ownership concentration. We adopt stricter criteria compared to previous studies investigating the US equity market (among others, Anderson \& Reeb, 2003a). These studies usually rely on a $20 \%$ ownership concentration threshold to identify family firms. Given the peculiarities of our setting, choosing such a threshold would not discriminate between the two groups. In addition, in accordance with Cascino et al. (2010), we seek to employ a more fine-grained definition of family firm that does not uniquely rely on ownership concentration as major discriminating factor. Therefore, we identify as family firms those in which $50 \%$ of the voting rights or outstanding shares (either direct or indirect) are held from a family block-holder. Furthermore, we require that at least one member of the controlling family holds a top managerial position (CEO or Chairman).

As far as the first threshold, it is required that the family (this is, a group of individuals who belong to one family or more) owns more than half of the company shares. In order to check this requirement, the 2017 Reference Form, available at the B3 website, is used. Two scenarios are revealed. If the control of the observed company was exercised by: (i) a legal entity, the information was deepened until there were only individuals. Shares of individuals belonging to the same family at each level of shareholding control is calculated. This information is contained in session 15 (Economic Group), paragraph 15.4 (Shareholders' Organization Chart and Economic Group) of the RF; (ii) a Group of companies/individuals defined as controlling. In this case, the threshold of 50\%+ of the shares owned by individuals belonging to the same family was applied to the controlling group. According to Law 6404/1976, as amended by Law 10303/2001, art. 116, a controlling shareholder means a natural or juridical person or a group of persons bound by a voting agreement, or under common control, who (i) holds shareholder rights that permanently grant majority of votes in the deliberations of the general assembly and the power to elect a majority of the company's administrators; and (ii) effectively uses its power to manage the company. This information is contained in RF's paragraph 15.5 (Shareholders' Agreement).

If the first condition is satisfied (this is, the so-called ultimate controller is one or more families), the management control requirement was, then, tested.

In RF's session 12 (General Assembly and Administration), paragraph 12.5 (Board of Directors) and 12.9 (Family Relations), analysis of the Board Members composition is available. If a family member is Chairman or CEO of the observed company, then the family management control was assumed and when the share and the management control conditions were both satisfied the company was classified as family-run. 
As far as to the calculation of the variable Earnings Management, evidence from prior studies suggest discretionary (abnormal) accruals as generally accepted proxy for accounting (or accruals) earnings management.

Based on Jones (1991), total accruals $\left(\mathrm{TA}_{\mathrm{it}}\right)$ are calculated as the difference between earnings (net result: $\left.\mathrm{RES}_{\mathrm{it}}\right)$ and operating cash flows $\left(\mathrm{CFO}_{\mathrm{it}}\right)$. This is: $\mathrm{TA}_{\mathrm{it}}=\mathrm{RES}_{\mathrm{it}}-\mathrm{CFO}_{\mathrm{it}}$.

Many models decompose total accruals, determined as above, into the discretionary and nondiscretionary component.

The original Jones model mainly calculated the non-discretionary accruals as a function of the (change in) sales and fixed assets (property, plant, and equipment). Dechow, Sloan and Sweeney (DSS, 1995) modified the Jones formula netting the change in sales by the change in receivables while Kothari, Leone and Wasley (KLW, 2002) added the variable return on asset (this is, Result and, then, scaling by previous year Total Asset), resulting in the following equation (Cohen, \& Zarawin, 2010):

$$
\mathrm{NA}_{i t}=\beta_{1 \mathrm{t}}\left(1 / \mathrm{A}_{\mathrm{it}-1}\right)+\beta_{2 \mathrm{t}}\left(\Delta \mathrm{REV}_{\mathrm{it}}-\Delta \mathrm{REC} \mathrm{C}_{\mathrm{it}}\right) / \mathrm{A}_{\mathrm{it}-1}+\beta_{3 \mathrm{t}} \mathrm{PPE}_{\mathrm{it}} / \mathrm{A}_{\mathrm{it}-1}+\beta_{4 \mathrm{t}} \mathrm{RES}_{\mathrm{it}} / \mathrm{A}_{\mathrm{it}-1}
$$

where: $\mathrm{NA}_{i \mathrm{t}}=$ Normal accruals for firm $\mathrm{i}$ in year $\mathrm{t} ; \Delta \mathrm{REV}_{\mathrm{it}}=$ Revenues for year $\mathrm{i}$ in year $\mathrm{t}$ less revenues in year $\mathrm{t}-1 ; \Delta \mathrm{REC}_{\mathrm{it}}=$ Receivables for firm $\mathrm{i}$ in year $\mathrm{t}$ less receivables in year $\mathrm{t}-1 ; \mathrm{PPE}_{\mathrm{it}}=\mathrm{Gross}_{\mathrm{s}}$ Property, plant and equipment for firm $\mathrm{i}$ in year $\mathrm{t}$; $\mathrm{RES}_{\mathrm{it}}=$ net result for firm $\mathrm{i}$ in year $\mathrm{t} ; \mathrm{A}_{\mathrm{it}-1}=$ Total Assets in year t-1.

Later, Kothari, Leone and Wasley (2005) edited a different version of the cited article, adding to the described model, the linear coefficient. This modification is inconsistent with the fact that the above model is an update of the DSS's (1995), which modified the original Jones's (1991) which was built using a weighted regression and excluding the intercept from the OLS regression. The same authors, in the modified version, state that the constant does not make a significant difference. For sensitivity purposes, we have calculated the earnings management variable, under the EMi metric, including the intercept, as per the following equation:

$$
N A_{i t}=\alpha_{0}+\beta_{1 t}\left(1 / A_{i t-1}\right)+\beta_{2 t}\left(\Delta R E V_{i t}-\Delta R E C_{i t}\right) / A_{i t-1}+\beta_{3 t} P P E_{i t} / A_{i t-1}+\beta_{4 t} R S_{i t} / A_{i t-1}
$$

Consequently, normal (or non-discretionary) accruals are fitted values of the above models and discretionary accruals are determined as the residuals. In other terms, discretionary accruals $\left(\mathrm{DA}_{\mathrm{it}}\right)$, a proxy of EM, is the difference between total accruals $\left(\mathrm{TA}_{\mathrm{it}}\right)$, defined as above and scaled by previous year total assets, and the fitted normal accruals calculate as per previous Equations (1) and (1i). This is: $\mathrm{DA}_{\mathrm{it}}=\left(\mathrm{TA}_{\mathrm{it}} / \mathrm{A}_{\mathrm{it}-1}\right)-\mathrm{NA}_{\mathrm{it}}$.

All the equations are run per any single observed year $t$, and the variables included are scaled by total assets in year $\mathrm{t}-1$, to mitigate heteroscedasticity issues.

We test our hypothesis using unsigned EM values which is a common practice in both accounting and finance literature because, first, discretionary accruals reverse over time and, second, they can be used to both inflate and deflate earnings.

Once the dependent variable (EM) and the main independent (Family Control) are calculated, we can answer the first research question, and, thus, investigate the relationship between EM and the family control presence by regressing the family control dummy with several control variables against the dependent, as follows:

$$
\mathrm{EM}_{\mathrm{it}}=\alpha_{0}+\beta_{1} \mathrm{FAM}_{\mathrm{i} 17}+\beta_{2} \mathrm{AGE}_{\mathrm{i} 17}+\sum_{j=3}^{j=5} \beta_{\mathrm{j}} \mathrm{CGV}_{\mathrm{i} 17}+\sum_{j=6}^{j=9} \beta_{\mathrm{j}} \mathrm{FCV}_{\mathrm{it}}+\varepsilon_{\mathrm{it}}
$$

Through the derived following models, we can test the second research hypothesis, this is the mediation role of age between family control and earnings management: 


$$
\begin{aligned}
& \mathrm{EM}_{\mathrm{it}}=\alpha_{0}+\beta_{1} \mathrm{FAMo}_{\mathrm{i} 17}+\beta_{2} \mathrm{FAMy}_{\mathrm{i} 17}+\beta_{3} \mathrm{NFAMy}_{\mathrm{i} 17}+\sum_{j=4}^{j=6} \beta_{\mathrm{j}} \mathrm{CGV}_{\mathrm{i} 17}+\sum_{j=7}^{j=10} \beta_{\mathrm{j} F C V}+\varepsilon_{\mathrm{it}} \\
& \mathrm{EM}_{\mathrm{it}}=\alpha_{0}+\beta_{1} \mathrm{FAMo}_{\mathrm{i} 17}+\beta_{2} \mathrm{FAMy}_{\mathrm{i} 17}+\beta_{3} \mathrm{NFAMo}_{\mathrm{i} 17}+\sum_{j=4}^{j=6} \beta_{\mathrm{j}} \mathrm{CGV}_{\mathrm{i} 17}+\sum_{j=7}^{j=10} \beta_{\mathrm{j}} \mathrm{FCV}_{\mathrm{it}}+\varepsilon_{\mathrm{it}}
\end{aligned}
$$

where: $\mathrm{EM}_{\mathrm{it}}$ is the Earnings Management variable for the firm $\mathrm{i}$ in year $\mathrm{t}$ calculated under the models expressed in Equations [1] and [1i] and $\mathrm{FAM}_{\mathrm{i} 17}$ is the family control dummy (=1 if the ultimate shareholder is a family; 0 otherwise) of the company $i$ at the latest date available. In the model under

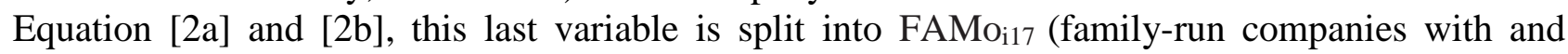
incorporation age above the median) and FAMyi17 (below) to appreciate the family life-cycle stage impact on the dependent. The non-family run companies are also split into young (NFAMyi17) and old (NFAMoi17). The use of the median to segment companies into old and young is common practice in recent literature (among others: Capasso, Gallucci, \& Rossi, 2015; Amore et al., 2017). In order to test the findings deriving from Equations [2a] and [2b], the segmentation of the family and non-family (controlled) company by age will be additionally done using the quartiles cut-off criteria as well, defining as old and young, respectively, the company older than the third quartile (P75) and younger then the first quartile (P25) of the full country's sample.

The choice of corporate governance and financial control variables was done on the basis of the best literature on family business, in accordance with Favero et al. (2009) which states that the use of explanatory variables will depend on the experience and common sense of the researcher in relation to the justification for inclusion of certain variables in the vector of variables $\mathrm{X}$, so as to support their insertion into the regression model.

The corporate governance variables (CGV), calculated for the firm i at the latest available date, are: STU is the state control dummy (=1 if the State is, directly or indirectly, the ultimate controller); DCS is the dual class shares dummy ( $=1$ if the company issue common and preferred shares); IND is a measure of board independence, which is estimated as the percentage of independent directors on the board.

STU, a proxy of institutional ownership, should generally exercise a positive effect on governance and hence on the level of accounting quality. At the same time, following the entrenchment hypothesis (Fan, \& Wong, 2002) it also seems plausible that institutional owners might decide to collude with managers to withhold information internally with negative consequences for accounting quality. Consequently, coherently with prior studies (Cascino et al., 2010), we make no sign prediction on this variable.

A positive relationship between DCS and the dependent is expected. Francis et al. (2005) examine the relation between earnings and dividend informativeness and stock classes in the U.S. context. They find that the earnings of firms with dual-class equity structures are less informative than earnings of firms with single class equity structures. Their findings may indicate an entrenchment effect of founding family ownership on earnings quality because dual class firms tend to have higher ownership concentration. Recently, Li and Zaiats (2017) find that dual class status is associated with poorer information environment and increased accrual-based earnings management, consistent with the notion that managers of dual class firms exhibit incentives to conceal private control benefits from the outside shareholders. Villalonga and Amit (2006) find that families use dual-class stock as a control-enhancing mechanism. Gompers, Ishii and Metrick (2009) suggest that insiders with greater private benefits are more likely to set up a dual-class stock structure.

As to IND, a proxy of board independence, Prencipe, Markarian and Pozza (2008) illustrate that the corporate governance literature advances the idea that certain aspects of a board of directors' structure improve the monitoring of managerial decisions, as earnings management policies. Studies show that earnings management in public companies is less prevalent when there is a high level of board independence (Klein, 2002; Xie, Davidson, \& Dadalt, 2003; Peasnell, Pope, \& Young, 2005; 
Jaggi, Leung, \& Gul, 2009). However, there is less evidence regarding the effectiveness of board independence on earnings manipulation in family-controlled companies

Financial control variables (FCV), calculated for the firm i in year t, are: LTA is the natural logarithm of the total asset; LEV is the leverage ratio calculated as financial debt as a percentage of the total asset; ROA is the return on asset ratio; GWT is the growth in sales.

LTA variable is included to control the company size. Monroe and Teh (1993) believe that size represents a firm's financial health and as such larger firms are generally seen to be healthy, while Carey and Simnett (2006) state that large companies have greater negotiating power and are less likely to end up in bankruptcy.

As to LEV, Iudícibus and Lopes (2004) and Martinez and De Paula Faria (2008), among others, demonstrated that discretionary accruals and debt ratios move in the same direction. Consequently, a positive correlation with the dependent is expected.

ROA, as an indicator of a poor financial health/profitability, is indicated by prior studies (Monroe, \& Teh, 1993; Dopuch, Holthausen, \& Leftwich, 1987), to have a negative correlation with EM variable. According to Cascino et al. (2010), high levels of profitability (ROA) signal the presence of economic rents. These rents could proxy for a rich investment opportunity set which calls for additional external financing and hence provides an incentive for higher quality financial information. On the other hand, these economic rents might be contestable by competitors and leading to higher proprietary costs, which negatively affect the quality of financial reporting information (Lambert, Leuz, \& Verrecchia, 2007). As a consequence, following previous studies on the determinants of financial reporting quality, we make no sign prediction for profitability.

As to GWT, the literature demonstrates that fast-growing firms are also likely to have noisier accruals. Consequently, we expect this variable to be positively associated with accrual quality (Reynolds, \& Francis, 2000; Chung, \& Kallapur, 2003; Wang, 2006; Auhbaugh Skaife et al., 2009). Finally, proposed equations, under [2], [2a] and [2b] are controlled for industry sector (divided into industry, service, commerce) and year fixed effect.

\section{RESULTS}

In the following tables are presented the descriptive statistics of metric (Table 1) and binary variables (Table 2) included in the present study.

Table 1 - Metric Variables Statistics

\begin{tabular}{lrrrrr}
\hline \multicolumn{1}{c}{ Variable } & Avg & \multicolumn{1}{c}{ StD } & \multicolumn{1}{c}{ P25 } & \multicolumn{1}{c}{ P50 } & \multicolumn{1}{c}{ P75 } \\
\hline EM & 0,10 & 0,14 & 0,03 & 0,06 & 0,12 \\
EMi & 0,12 & 0,14 & 0,04 & 0,08 & 0,14 \\
AGE & 48,44 & 31,96 & 20,00 & 46,00 & 67,00 \\
IND & 89,77 & 13,85 & 85,71 & 92,31 & 100,00 \\
LTA & 6,82 & 1,51 & 5,91 & 6,88 & 7,80 \\
LEV & 0,34 & 0,26 & 0,19 & 0,32 & 0,45 \\
ROA & 0,00 & 0,21 & $(0,01)$ & 0,02 & 0,07 \\
GWT & 0,09 & 0,88 & $(0,16)$ & $(0,01)$ & 0,18 \\
\hline
\end{tabular}

$\mathrm{P} 25=1^{\text {st }}$ quartile; $\mathrm{P} 50=2^{\text {nd }}$ quartile (or median); $\mathrm{P} 75=3^{\text {rd }}$ quartile

$\mathrm{EM}=$ Earnings Management calculated as per Equation [1]; EMi $=$ as per Equations [1i]; AGE $=$ numbers of years since incorporation; IND $=$ the percentage of independent board directors; $\mathrm{LTA}=$ the natural logarithm of the total asset; $\mathrm{LEV}=$ leverage ratio calculated as financial debt as percentage of the total asset; ROA = return on asset ratio; GWT $=$ growth in sales

Table 2 - Binary Variables Frequency

\begin{tabular}{lrr}
\hline \multicolumn{1}{c}{ Variable } & $\mathbf{0}$ & $\mathbf{1}$ \\
\hline FAM & $61,6 \%$ & $38,4 \%$ \\
FAMo (> P50) & $76,8 \%$ & $23,2 \%$ \\
FAMy (< P50) & $84,8 \%$ & $15,2 \%$ \\
NFAMo (> P50) & $72,8 \%$ & $27,2 \%$ \\
NFAMy (<P50) & $65,6 \%$ & $34,4 \%$ \\
STU & $90,7 \%$ & $9,3 \%$ \\
DCS & $88,1 \%$ & $11,9 \%$ \\
\hline
\end{tabular}

$<$ (or >) P50 means company younger (or older) than 2nd quartile (or median)

FAM $=$ family firm; NFAM = non family firm; FAMo = family-run companies with an incorporation age above the median; FAMy = below; $\mathrm{STU}=1$ if the State is the ultimate controller; DCS $=1$ if the company issues common and preferred shares

The purpose of this statistics is to have an overall idea of the data set we are analyzing. Main findings are: (i) the two earnings management metrics, EM being calculated using Equation [1] (KLW, 2002) and EMi using Equation [1i] (KLW, 2005), return similar values; (ii) the average incorporation age is 48 years, similar to the cut-off age used by Anderson and Reeb (2003); (iii) 
around $38 \%$ of the companies has one or more families as a ultimate owner; (iv) the median (age) separates this group into old $(23 \%)$ and young $(15 \%)$ family firms (v) same analysis by age can be done for the non-family firms' group which accounts for the $62 \%$ of the sample; (vi) around $9 \%$ of the firms sample has the State as ultimate owner and (vii) around $12 \%$ issue both common and preferred shares.

As to the univariate analysis between the models' metric variables, Pearson and Spearman correlations, as per the following Table 3 , show that both absolute discretionary accruals metrics have a significant (negative) correlation with the age variable, justifying the second research question. This finding was already obtained in previous studies (Wang, 2006) but the underlying reason remained unexplained.

Both EM metrics also demonstrate a negative correlation with the company size, confirming studies (Monroe \& The, 1993) which consider this variable as a proxy of firm's financial health. Carey and Simnett (2006) state that large companies have greater negotiating power and are less likely to end up in bankruptcy.

ROA also shows a significant (negative) correlation, but under the without constant EM formula. Prior studies (Monroe, \& Teh, 1993; Dopuch, Holthausen, \& Leftwich, 1987) indicate a negative correlation between these two variables and a recent study (Tommasetti et al., 2018) confirmed this result in the Brazilian context, as to say that healthy companies do not "need" to engage in EM practices.

Finally, the two EM metrics show an expected high correlation between them.

Table 3 - Variables' Correlation

\begin{tabular}{|c|c|c|c|c|c|c|c|c|}
\hline Variable & EM & EMi & AGE & IND & LTA & LEV & ROA & GWT \\
\hline EM & & ,938** &,$- 110 * *$ &,- 062 &,$- 110 * *$ & $-0,01$ &,$- 077 *$ & ,066 \\
\hline EMi &, $740 * *$ & &,$- 076^{*}$ &,- 063 &,$- 088^{*}$ & $-0,04$ & $-0,04$ &, 020 \\
\hline AGE &,$- 133 * *$ & $-0,04$ & &,$- 177 * *$ &, $087 *$ &,$- 083 *$ & 0,062 &,- 048 \\
\hline IND & ,009 & ,059 &,$- 107 * *$ & & $119 * *$ &, $114 * *$ &,$- 087 *$ &, 013 \\
\hline LTA &,$- 100 * *$ & $-0,0702$ &, $074 *$ &, $080 *$ & &, $175^{* *}$ &, $092 *$ & 041 \\
\hline LEV & $-0,069$ &,$- 084 *$ & ,017 &, $099 * *$ &, $334 * *$ & &,$- 241 * *$ & ,029 \\
\hline ROA &, $158 * *$ &, $247 * *$ & 0,070 &,$- 075^{*}$ & ,064 &,$- 322 * *$ & &, $192 * *$ \\
\hline GWT & 0,050 &, $089 *$ &,- 001 &, 012 &, $154 * *$ &,- 010 & ,230** & \\
\hline
\end{tabular}

$\mathrm{EM}=$ Earnings Management calculated as per Equation [1]; EMi $=$ as per Equations [1i]; AGE = numbers of years since incorporation; IND = the percentage of independent directors on the board; LTA = the natural logarithm of the total asset; LEV = leverage ratio calculated as financial debt as percentage of the total asset; ROA $=$ return on asset ratio; GWT $=$ growth in sales. Pearson's values above diagonal; Spearman's below. $*=$ significant at the 0,05 level (2-tailed); ** $=$ at the 0,01 level (2-tailed)

Passing from the uni- to the multivariate analysis, for each regression model, the relevant outcome statistics are reported in the lower part of the related Table.

As pre-requisite of each regression, the normality and heteroscedasticity tests are run: the result of these two tests is, for each of the proposed models, that the distribution of this variables is both not normal ( $\mathrm{p}$-value $<0,01$ ) and not homo ( $\mathrm{p}$-value of the Wald test $<0,01$ ). For the normality issue, the Central Limit Theorem enables to state that, since the sample is big enough $(>30$ observations), the normality of the residuals can be assumed (Brooks, 2008). As to the heteroscedasticity issue, it is necessary to run the regression model with robust errors.

Multicollinearity diagnostics test did not detect VIF values above 10 for any of the variables in the regressions presented and for this reason, it can be concluded that there are no collinearity issues between the independent regressors. The coefficient with higher VIF value is presented for each regression data-set.

Tests are also needed to determine which kind of panel method is adequate to our dataset. When the p-values as result of the Chow is high(er than 0,01) and Hausmann test is low(er than 0,01), then the Breusch-Pagan test is unnecessary, since the choice is, respectively, not to reject the null hypothesis that the OLS Pooled method is to be preferred against the Fixed Effect and that the Fixed Effect has to be preferred to the Aleatory Effect, being the final decision to adopt the OLS Pooled 
method. When the latter condition is not respected, the Breusch-Pagan test p-value is shown and if, as in the case, is high (er than 0,01), again the OLS Pooled method is to be preferred (against the Aleatory Effect). In every model proposed, the OLS panel method appear to be adequate.

Consequently, we run a regression model to test the proposed Equation 2 in the balanced panel of the 151 firms (along the period) to verify the significance and the strength of the relationships. Results are presented in the following Table 4.

From Table 4, it can be deduced that the model is significant under both EM metrics with a satisfactory adjusted R Square.

As to the significance of financial control regressors, LTA confirmed their significant relation with the dependent under both EM metrics, the sign being in line with the previous literature while GWT demonstrates, under EM only, that fast-growing firms are also likely to have noisier accruals (Reynolds, \& Francis, 2000; Chung, \& Kallapur, 2003; Wang, 2006; Auhbaugh Skaife et al., 2009).

Among the corporate governance variables, DCS shows an un-expected negative sign but under EMi only.

As to the two main variables, in a prima facie analysis, FAM seems not to be significant in explaining EM. At the same time the negative (and significant) sign of the AGE variable, under EM metrics only, leads authors to deeper investigate if the family control relation with EM is linear or is somehow mediated by AGE.

Table 4 - Regression under Equation [2] results

\begin{tabular}{|c|c|c|c|c|c|c|}
\hline \multirow{2}{*}{$\begin{array}{c}\text { Dependent } \\
\text { Variables }\end{array}$} & \multirow{2}{*}{$\frac{\text { Exp'ed }}{\text { Sign }}$} & \multirow{2}{*}{$\begin{array}{c}\text { VIF } \\
\text { Values }\end{array}$} & \multicolumn{2}{|c|}{ EM } & \multicolumn{2}{|c|}{ Emi } \\
\hline & & & Coef & Sig & Coef & Sig \\
\hline Intercept & na & $\mathrm{Na}$ & 0,241 & $* * *$ & 0,252 & $* * *$ \\
\hline FAM & - & 1,21 & $(0,007)$ & & $(0,011)$ & \\
\hline AGE & - & 1,12 & $(4,6 \mathrm{E}-04)$ & $* *$ & $(2,9 \mathrm{E}-04)$ & \\
\hline STU & \pm & 1,28 & 0,009 & & 0,010 & \\
\hline DCS & + & 1,17 & 0,005 & & $(0,020)$ & $*$ \\
\hline IND & - & 1,12 & $(0,001)$ & & $(0,001)$ & \\
\hline LTA & - & 1,14 & $(0,009)$ & $* * *$ & $(0,007)$ & $* *$ \\
\hline LEV & + & 1,15 & 0,004 & & $(0,011)$ & \\
\hline ROA & \pm & 1,17 & $(0,061)$ & & $(0,034)$ & \\
\hline GWT & + & 1,12 & 0,014 & $* *$ & 0,005 & \\
\hline $\mathrm{R}^{2}$ & & & 0,22 & & 0,23 & \\
\hline Model p-value & & & $3,28 \mathrm{~F}$ & & $3,52 \mathrm{E}$ & \\
\hline Normality p-value & & & $3,2 \mathrm{E}$ & & $1,6 \mathrm{E}-$ & \\
\hline Homoschedacity p-value & & & $3,3 \mathrm{E}$ & & $1,7 \mathrm{E}$ & \\
\hline Chow & & & 0,7 & & 0,8 & \\
\hline Hausman & & & 0,5 & & 0,3 & \\
\hline Breusch-Pagan & & & 0,4 & & 0,3 & \\
\hline
\end{tabular}

EM = Earnings Management calculated as per Equation [1]; EMi = as per Equations [1i]; FAM = 1 if it is a family firm; AGE = numbers of years since incorporation; STU $=1$ if the State is the ultimate controller; DCS $=1$ if the company issues common and preferred shares; IND = the percentage of independent directors on the board; LTA $=$ the natural logarithm of the total asset; LEV = leverage ratio calculated as financial debt as percentage of the total asset; ROA $=$ return on asset ratio; GWT $=$ growth in sales. OLS Method w/HC errors. Fixed sector industry/year effect. * $=$ significant at the 0,10 level; $* *=$ at the 0,$05 ; * * *=$ at the 0,01

To this purpose, we segmented the whole firms' sample into 4 groups: FAMo (family-run companies with age above the whole sample median), FAMy (below), NFAMo (non-family control companies with age above the whole sample median) and NFAMy (below).

Then, we run the same regression under Equation [2], leaving, for comparison purposes, outside of the model, first the NFAMo (Equation [2a], Table 5, left side) and then NFAMy (Equation [2b], Table 5, right side).

From the left side of Table 5, we can conclude that old family companies show lower discretionary accruals than their non-family counterpart and (family or non) young companies while the right side of the table confirms this last finding. 
Finally, this out-of-scope finding being confirmed under EM metric only, among the nonfamily companies, the younger show higher discretionary accruals than the older.

After including industry and year fixed effects in all regressions, our findings shown remain unchanged. Results are omitted in the related tables for readability.

Table 5 - Regressions' outcome (OLS Method w/HC errors. Fixed industry/year effect. Obs.: 755)

\begin{tabular}{|c|c|c|c|c|c|c|c|c|c|c|c|}
\hline \multirow{2}{*}{$\begin{array}{l}\text { Equation [2a] } \\
\text { against NFAMo }\end{array}$} & \multirow{2}{*}{$\begin{array}{c}\text { Exp. } \\
\text { Sign }\end{array}$} & \multicolumn{2}{|l|}{ EM } & \multicolumn{2}{|c|}{ Emi } & \multirow{3}{*}{\begin{tabular}{|l|} 
Equation [2b] \\
against NFAMy \\
Intercept
\end{tabular}} & \multirow{3}{*}{$\begin{array}{c}\text { Exp. } \\
\text { Sign } \\
\text { n/a }\end{array}$} & \multicolumn{2}{|l|}{ EM } & \multicolumn{2}{|l|}{ Emi } \\
\hline & & Coef. & Sig & Coef & Sig & & & Coef. & Sig & Coef & Sig \\
\hline & $\mathrm{n} / \mathrm{a}$ & 0,190 & $* * *$ & 0,222 & $* * *$ & & & 0,210 & $* * *$ & 0,232 & $* * *$ \\
\hline FAMo & - & $(0,016)$ & $*$ & $(0,018)$ & $*$ & FAMo & - & $(0,036)$ & $* * *$ & $(0,029)$ & $* * *$ \\
\hline FAMy & $-\left({ }^{1}\right)$ & 0,032 & & 0,012 & & FAMy & $-\left({ }^{1}\right)$ & 0,012 & & 0,002 & \\
\hline NFAMy & $?$ & 0,020 & $* *$ & 0,010 & & NFAMo & $?$ & $(0,020)$ & $* *$ & $(0,010)$ & \\
\hline STU & \pm & 0,011 & & 0,011 & & STU & \pm & 0,011 & & 0,011 & \\
\hline DCS & + & 0,007 & & $(0,019)$ & $*$ & DCS & + & 0,007 & & $(0,019)$ & $*$ \\
\hline IND & - & $(0,001)$ & & $(0,001)$ & & IND & - & $(6,8 \mathrm{E}-04)$ & & $(7,3 \mathrm{E}-04)$ & \\
\hline LTA & - & $(0,009)$ & $* * *$ & $(0,008)$ & $* * *$ & LTA & - & $(0,009)$ & $* * *$ & $(0,008)$ & $* * *$ \\
\hline LEV & + & 0,009 & & $(0,007)$ & & LEV & + & 0,009 & & $(0,007)$ & \\
\hline ROA & \pm & $(0,062)$ & & $(0,035)$ & & ROA & \pm & $(0,062)$ & & $(0,035)$ & \\
\hline GWT & + & 0,015 & $* *$ & 0,006 & & GWT & + & 0,015 & $* *$ & 0,006 & \\
\hline \multicolumn{2}{|l|}{$\mathrm{R}^{2}$} & \multicolumn{2}{|c|}{0,2276} & \multicolumn{2}{|c|}{0,2371} & \multicolumn{2}{|l|}{$\mathrm{R}^{2}$} & \multicolumn{2}{|l|}{0,2276} & \multicolumn{2}{|l|}{0,2371} \\
\hline \multicolumn{2}{|l|}{ Model p-value } & \multicolumn{2}{|c|}{$1,1 \mathrm{E}-13$} & \multicolumn{2}{|c|}{$1,7 \mathrm{E}-14$} & \multicolumn{2}{|l|}{ Model p-value } & \multicolumn{2}{|l|}{$1,1 \mathrm{E}-13$} & \multicolumn{2}{|l|}{$1,7 \mathrm{E}-14$} \\
\hline \multicolumn{2}{|l|}{ Normality p-value } & \multicolumn{2}{|l|}{0,00} & \multicolumn{2}{|c|}{$2,6 \mathrm{E}-154$} & \multicolumn{2}{|l|}{ Normality p-value } & \multicolumn{2}{|l|}{0,00} & \multicolumn{2}{|l|}{$2,6 \mathrm{E}-154$} \\
\hline \multicolumn{2}{|c|}{ Homoschedacity p-value } & $1,1 \mathrm{E}-0$ & & $3,1 \mathrm{~F}$ & & \multirow{2}{*}{\multicolumn{2}{|c|}{$\begin{array}{l}\text { Homoschedacity p-value } \\
\text { Higher VIF }\end{array}$}} & $1,1 \mathrm{E}-08$ & & $3,1 \mathrm{E}-11$ & \\
\hline \multirow{2}{*}{\multicolumn{2}{|c|}{ Higher VIF }} & \multicolumn{4}{|c|}{$\mathrm{NFAMy}=1,679$} & & & \multicolumn{4}{|c|}{ NFAMo $=1,471$} \\
\hline & & \multicolumn{2}{|l|}{0,853} & 0,8 & & Chow & & 0,853 & & 0,883 & \\
\hline Hausman & & 0,580 & & 0,3 & & Hausman & & 0,580 & & 0,330 & \\
\hline Breusch-Pagan & & 0,303 & & 0,2 & & Breusch-Pagan & & 0,303 & & 0,225 & \\
\hline $\begin{array}{l}\text { (1) sign expected to b } \\
0,01 \text {. EM = Earnings } \\
\text { age above the median } \\
\text { and preferred shares; } \\
\text { calculated as financia } \\
\text { sector industry/year e }\end{array}$ & gativ & $\begin{array}{l}\text { 1) and coe } \\
\text { calculated } \\
\text { ow; NFAN } \\
\text { centage of }\end{array}$ & effic & $\begin{array}{l}\text { higher tha } \\
\text { quation [ }\end{array}$ & the $\mathrm{F}$ & $\begin{array}{l}\mathrm{o}(\mathrm{H} 2) \cdot{ }^{*}=\text { signific } \\
\text { s per Equations [1i] } \\
\text { f the State is the ulti }\end{array}$ & at the 0 & $\begin{array}{l}\text { 2-tailed); } \\
\text { ly-run comp } \\
\text { DCS }=1 \text { if tl } \\
\text { of the total }\end{array}$ & $=a$ & $\begin{array}{l}0,05 ; * * *= \\
\text { th an incorpo } \\
\text { any issues co } \\
\mathrm{EV}=\text { leverag }\end{array}$ & at the \\
\hline
\end{tabular}

We can summarize the findings of the within groups relationship in terms of higher $(>)$ or lower $(<)$ or not different $(=)$ propensity to EM practices, as per the following Table 6 .

Table 6 - Intergroups relationships

\begin{tabular}{lllcccc}
\hline & & & Expected & EM & EMi & \\
\hline 1 & H1 & FAMo & $<$ & $<$ & $<$ & NFAMo \\
2 & H1 & FAMo & $<$ & $<$ & $<$ & NFAMy \\
3 & H1 & FAMy & $<$ & $=$ & $=$ & NFAMo \\
4 & H1 & FAMy & $<$ & $=$ & $=$ & NFAMy \\
5 & H2 & FAMo & $<$ & $<$ & $<$ & FAMy \\
\hline
\end{tabular}

From the above results, it can be stated that $\mathrm{H} 1$ hypothesis, this is family firms indulge less in EM than non-family, is confirmed but uniquely for old family-run companies (Table 6, lines 1 and 2 ). On the other hand, $\mathrm{H} 2$ hypothesis (older family firms indulge less in EM than younger) is confirmed by both models and under EM metrics (line 5).

Results, as per previously presented tables 5 and 6, are confirmed under both EM metrics, adding - under EM metric and the quartile sensitivity case only - that FAMy companies indulge more than NFAM companies in earnings management practices. The limited number of observations under the quartile segmentation (the young family group under the quartile cut-off is formed by 8 firms and the old one by 15 out of 151 selected firms) represents a limitation.As to the relationships within the non-family segment in terms of EM propensity, the result seems consistent with previous literature that shows as age is positively related to good corporate governance practices (Ariff, Ibrahim, \& Othman, 2007; Almeida, \& Santos, 2008). 
As to the corporate governance and financial control variable, their sign and related comments per age segmentation are the same resulting from Table 4.

\section{CONCLUSIONS}

The aim of the present study is to investigate the influence of the family control in the quality of earnings and, more specifically, to better understand if, within family firms, the propensity to earnings management practices changes with the passage of time.

The outcome of our research is that the relationship between the family control and the earnings management is mediated by age as old family firms engage less than any other group in earning management practices and that, within the family firms group, the entrenchment effect is prevalent on the natural alignment effect between managers and ownership in the first-generation stage, inverting their weights in the later generation stage, confirming the second research hypothesis.

These findings are in line with the socioemotional theory that posits that the (socioemotional) wealth is strongest in the founding-family-controlled stage (this is younger family firms) and lower in later generational stages. Gómez-Mejía et al. (2007) find that the willingness to relinquish family control is lowest in earlier generational stages when socioemotional wealth is highest. These observations suggest that when successive generations enter the firm, the focus shifts from family objectives to a combination of family and business objectives. As more and more generations are involved in the business, more formal governance mechanisms tend to be necessary to manage the interests of these different family branches (Jaffe, \& Lane, 2004) and if independent boards are installed, then both family and business interests are protected. Hence, the likelihood that family firms focus mainly on family objectives reduces.

Finally, in multigenerational firms, ownership is likely to be dispersed, including a growing amount of passive family members (Jaffe, \& Lane, 2004). These passive family members tend to be less overinvested in the family firm so that their risk preferences are like those of outside investors in public firms (Schulze, Lubatkin, \& Dino, 2002). Hence, these family members are expected to behave more as diversified investors and will, therefore, dedicate more attention to business objectives. Consequently, family firms in later generational stages attach less weight to preserving socioemotional wealth and thus have less incentive to engage in upward earnings management than firms in the controlling owner stage. Following this theory, in a sample of private Flemish firms, Stockmans, Lybaert and Voordeckers (2010) show that both second- and third- and later generation family firms perform less upward earnings management than do first-generation family firms.

This result can be also read under the agency theory theoretical framework. Keasey, Martinez and Pindado (2015) show the non-dilution entrenchment effect, and the related need for the firm to issue more debt, a financing source with less loss of control for listed firms, is stronger when the business is a young family firm. Westhead (2003) finds that first generation firms are significantly more likely than multigenerational firms to report that family objectives have priority over business objectives: young family firms are typically characterized by the presence of the founder, who may be reluctant to dilute family control given their long-term perspective. However, as a family firm grows older, more succession conflicts arise, and the dilution of the family stake can be needed.

Within non-family firms, older firms show a lower level of discretionary accruals uniquely under the without intercept EM model, consistently with many studies which demonstrate that age is positively related to good corporate governance practices (Ariff, Ibrahim, \& Othman, 2007; Almeida, \& Santos, 2008).

The present paper suggests agency theory, as socio-emotional theory (Stockmans, Lybaert \& Voordeckers, 2010), both describe a similar approach of the family towards earnings management decision along the time.

The study also contributes to the debate of family firm heterogeneity. Although studies have acknowledged that family firms are a heterogeneous group (Sharma, 2004), up until now research on 
earnings management in public family firms has mainly considered family firms to be a homogeneous group. On the contrary, results suggest that there is a heterogeneity of propensity towards earnings management practices among family firms, depending on their age

Furthermore, findings also fuel the debate on risk behaviour in family firms. The family firms' literature often portrays family firms as having a long-term vision or patient capital. We demonstrated that in terms of accounting earnings management, their approach became virtuous just with the passage of time.

From a practical point of view, this paper could help non-family stakeholders in making more accurate credit decisions. These results could have managerial implications for family owners: the longevity could emerge as a value driver that associations can exploit in both institutional and investors relations communication. Longevity and family components are two concepts with high evocative and symbolic content.

This study is of interest to financial statement users, including analysts and investors, or policy makers and standard setters as it shows that different company types (e.g., family vs. non-family) at a different stage of the life-cycle (young vs old) have a different attitude towards earnings quality. The conclusions also are of interest to auditors when evaluating the reliability of the reported income of companies characterized by various ownership structures.

\section{REFERENCES}

Abdolmohammadi, M., Kvaal, E., \& Langli, J. C. (2010). Earnings management priorities of private family firms. Norwegian School of Management Working Paper No. 3/2010.

Almeida, M., \& Santos, J. (2008). Relação entre variáveis endógenas e a qualidade das práticas de governança corporativa das empresas brasileiras de capital aberto não listadas em bolsa. Revista de Informação Contábil, 2(4), 17-37.

Amore, M. D., Caselli, S., Colla, P., \& Corbetta, G. (2017). Board Connections and Debt Structure in Private Firms. Available at SSRN 2821465.

Anderson, R. C., \& Reeb, D. M. (2003). Founding-family ownership and firm performance: evidence from the S\&P 500. The Journal of Finance, 58(3), 1301-1328.

Ariff, A. M., Ibrahim, M. K., \& Othman, R. (2007). Determinants of firm level governance: Malaysian evidence. Corporate Governance: The International Journal of Business in Society, 7(5), 562573.

Ashbaugh-Skaife, H., Collins, D. W., Kinney Jr, W. R., \& LaFond, R. (2009). The effect of SOX internal control deficiencies on firm risk and cost of equity. Journal of Accounting Research, 47(1), 1-43.

Barroso, A., González-López, Ó., Sanguino, R., \& Buenadicha-Mateos, M. (2018). Analysis and evaluation of the largest 500 family firms' websites through PLS-SEM technique. Sustainability, 10(2), 557.Brooks, C. (2008). Handbook to Accompany Introductory Econometrics for Finance. Cambridge Books.

Carey, P., \& Simnett, R. (2006). Audit partner tenure and audit quality. The Accounting Review, 81(3), 653-676.

Capasso, A., Gallucci, C., \& Rossi, M. (2015). Standing the test of time. Does firm performance improve with age? An analysis of the wine industry. Business History, 57(7), 1037-1053.

Cascino, S., Pugliese, A., Mussolino, D., \& Sansone, C. (2010). The influence of family ownership on the quality of accounting information. Family Business Review, 23(3), 246-265.

Chen, S., Chen, X. I. A., \& Cheng, Q. (2008). Do family firms provide more or less voluntary disclosure?. Journal of Accounting Research, 46(3), 499-536.

Chrisman, J. J., Chua, J. H., \& Kellermanns, F. (2009). Priorities, resource stocks, and performance in family and nonfamily firms. Entrepreneurship Theory and Practice, 33(3), 739-760.

Chrisman, J. J., Chua, J. H., \& Sharma, P. (2005). Trends and directions in the development of a strategic management theory of the family firm. Entrepreneurship Theory and Practice, 29(5), 555-575.

Chu, W. (2011). Family ownership and firm performance: Influence of family management, family control, and firm size. Asia Pacific Journal of Management, 28(4), 833-851. 
Chung, H., \& Kallapur, S. (2003). Client importance, nonaudit services, and abnormal accruals. The Accounting Review, 78(4), 931-955.

Cohen, D. A., \& Zarowin, P. (2010). Accrual-based and real earnings management activities around seasoned equity offerings. Journal of Accounting and Economics, 50(1), 2-19.

Dechow, P. M., Sloan, R. G., \& Sweeney, A. P. (1995). Detecting earnings management. The Accounting Review, 193-225.

Demsetz, H., \& Lehn, K. (1985). The structure of corporate ownership: Causes and consequences. Journal of Political Economy, 93(6), 1155-1177.

Diamond, D. W., \& Verrecchia, R. E. (1991). Disclosure, liquidity, and the cost of capital. The Journal of Finance, 46(4), 1325-1359.

Dopuch, N., Holthausen, R. W., \& Leftwich, R. W. (1987). Predicting audit qualifications with financial and market variables. The Accounting Review, 431-454.

Ensley, M. D., \& Pearson, A. W. (2005). An exploratory comparison of the behavioral dynamics of top management teams in family and nonfamily new ventures: Cohesion, conflict, potency, and consensus. Entrepreneurship Theory and Practice, 29(3), 267-284.

Fama, E. F., \& Jensen, M. C. (1983). Separation of ownership and control. The Journal of Law and Economics, 26(2), 301-325.

Fan, J. P., \& Wong, T. J. (2002). Corporate ownership structure and the informativeness of accounting earnings in East Asia. Journal of Accounting and Economics, 33(3), 401-425.

Fasolin, L. B., \& Klann, R. C. (2015). Gerenciamento De Resultados Por Accruals Específicos em Empresas Familiares Brasileiras. In: Anais do Congresso Anpcont (IX).

Fávero, L. P. L., Belfiore, P. P., Silva, F. L. D., \& Chan, B. L. (2009). Análise de dados: modelagem multivariada para tomada de decisões. Campus, São Paulo.

Filatotchev, I., Lien, Y. C., \& Piesse, J. (2005). Corporate governance and performance in publicly listed, family-controlled firms: Evidence from Taiwan. Asia Pacific Journal of Management, 22(3), 257283.

Firth, M., Fung, P. M., \& Rui, O. M. (2007). Ownership, two-tier board structure, and the informativeness of earnings-Evidence from China. Journal of Accounting and Public Policy, 26(4), 463-496.

Francis, J., LaFond, R., Olsson, P., \& Schipper, K. (2005). The market pricing of accruals quality. Journal of Accounting and Economics, 39(2), 295-327.

Gavana, G., Gottardo, P., \& Moisello, A. (2017). Earnings management and CSR disclosure. Family vs. nonfamily firms. Sustainability, 9(12), 2327.

Gersick, K. E. (1997). Generation to Generation: Life cycles of the family business. Harvard Business Press.

Gómez-Mejía, L. R., Haynes, K. T., Núñez-Nickel, M., Jacobson, K. J., \& Moyano-Fuentes, J. (2007). Socioemotional wealth and business risks in family-controlled firms: Evidence from Spanish olive oil mills. Administrative Science Quarterly, 52(1), 106-137.

Gompers, P. A., Ishii, J., \& Metrick, A. (2009). Extreme governance: An analysis of dual-class firms in the United States. The Review of Financial Studies, 23(3), 1051-1088.

Graham, J. R., Harvey, C. R., \& Rajgopal, S. (2005). The economic implications of corporate financial reporting. Journal of Accounting and Economics, 40(1-3), 3-73.

Iudícibus, S., Lopes, A. B. (2004). Teoria Avançada da Contabilidade. São Paulo: Atlas.

Jaffe, D. T., \& Lane, S. H. (2004). Sustaining a family dynasty: Key issues facing complex multigenerational business-and investment-owning families. Family Business Review, 17(1), 81-98.

Jaggi, B., Leung, S., \& Gul, F. (2009). Family control, board independence and earnings management: Evidence based on Hong Kong firms. Journal of Accounting and Public Policy, 28(4), 281-300.

Jiraporn, P., \& DaDalt, P. J. (2009). Does founding family control affect earnings management?. Applied Economics Letters, 16(2), 113-119.

Jones, J. J. (1991). Earnings management during import relief investigations. Journal of Accounting Research, 29(2), 193-228.

Jung, K., \& Kwon, S. Y. (2002). Ownership structure and earnings informativeness: Evidence from Korea. The International Journal of Accounting, 37(3), 301-325.

Keasey, K., Martinez, B., \& Pindado, J. (2015). Young family firms: Financing decisions and the willingness to dilute control. Journal of Corporate Finance, 34, 47-63. 
Klein, A. (2002). Audit committee, board of director characteristics, and earnings management. Journal of Accounting and Economics, 33(3), 375-400.

Kothari, S. P., Leone, A. J., \& Wasley, C. E. (2002). Performance matched discretionary accrual measures (April). Simon School of Business Working Paper No. FR 01-04; MIT Sloan Working Paper No. 4335-01.

Kothari, S. P., Leone, A. J., \& Wasley, C. E. (2005). Performance matched discretionary accrual measures. Journal of Accounting and Economics, 39(1), 163-197.

Lambert, R., Leuz, C., \& Verrecchia, R. E. (2007). Accounting information, disclosure, and the cost of capital. Journal of Accounting Research, 45(2), 385-420.

Leite, R.; Carvalhal, A. (2016). Firm age, value, performance and corporate governance in Brazil. Corporate Ownership \& Control, 13(4), 8-12.

Li, T., \& Zaiats, N. (2017). Information environment and earnings management of dual class firms around the world. Journal of Banking \& Finance, 74, 1-23.

Martinez, A. L., \& Faria, M. D. P. (2007). Emissão de debêntures e earnings management no Brasil. Revista de Informação Contábil, 2(1), 57-71.

Monroe, G. S., \& Teh, S. T. (1993). Predicting uncertainty audit qualifications in Australia using publicly available information. Accounting \& Finance, 33(2), 79-106.

Morck, R., Shleifer, A., \& Vishny, R. W. (1988). Management ownership and market valuation: An empirical analysis. Journal of Financial Economics, 20, 293-315.

Moreira Júnior, A. L., \& Bortoli Neto, A. (2007). Empresa Familiar: Um Sonho Realizado. São Paulo: Saraiva.

Peasnell, K. V., Pope, P. F., \& Young, S. (2005). Board monitoring and earnings management: do outside directors influence abnormal accruals?. Journal of Business Finance \& Accounting, 32(7-8), 13111346.

Prencipe, A., \& Bar-Yosef, S. (2011). Corporate governance and earnings management in family-controlled companies. Journal of Accounting, Auditing \& Finance, 26(2), 199-227.

Prencipe, A., Markarian, G., \& Pozza, L. (2008). Earnings management in family firms: Evidence from R\&D cost capitalization in Italy. Family Business Review, 21(1), 71-88.

Reynolds, J. K., \& Francis, J. R. (2000). Does size matter? The influence of large clients on office-level auditor reporting decisions. Journal of Accounting and Economics, 30(3), 375-400.

Salvato, C., \& Moores, K. (2010). Research on accounting in family firms: Past accomplishments and future challenges. Family Business Review. 23(3) 193-215.

Schulze, W. S., Lubatkin, M. H., \& Dino, R. N. (2002). Altruism, agency, and the competitiveness of family firms. Managerial and Decision Economics, 23(4-5), 247-259.

Setia-Atmaja, L., Tanewski, G. A., \& Skully, M. (2009). The role of dividends, debt and board structure in the governance of family controlled firms. Journal of Business Finance \& Accounting, 36(7-8), 863-898.

Sharma, P. (2004). An overview of the field of family business studies: Current status and directions for the future. Family Business Review, 17(1), 1-36.

Shleifer, A., \& Vishny, R. W. (1986). Large shareholders and corporate control. Journal of Political Economy, 94(3, Part 1), 461-488.

Silva, G. E., De Oliveira, G. J., da Silva Macedo, M. A., \& da Costa Marques, J. A. V. (2016). Análise do Impacto do Controle Familiar sobre a Qualidade das Informações Contábeis no Brasil: um estudo com foco na análise de relevância do lucro. Revista de Finanças Aplicadas, 4(1), 1-30.

Stockmans, A., Lybaert, N., \& Voordeckers, W. (2010). Socioemotional wealth and earnings management in private family firms. Family Business Review, 23(3), 280-294.

Tiscini, R., \& Di Donato, F. (2008). The impact of family control and corporate governance practices on earnings quality of listed companies: A study of the Italian case. Available at SSRN 1346457.

Tommasetti, R., Santos, N. M. B. F., Macedo, M. A. D. S., \& Neto, A. S. (2018). Relationship between modified audit opinion, earnings management and auditor size: evidence from Brazil. Pensar Contábil, 20(72).

Torres, D., Bruni, A. L., Castro, M. Á. R., \& Martinez, A. L. (2010). Estrutura de propriedade e controle, governança corporativa e o alisamento de resultados no Brasil. Revista Contemporânea de Contabilidade, 7(13), 11-34. 
Van Gils, A., Voordeckers, W., \& van den Heuvel, J. (2004). Environmental uncertainty and strategic behavior in Belgian family firms. European Management Journal, 22(5), 588-595.

Villalonga, B., \& Amit, R. (2006). How do family ownership, control and management affect firm value?. Journal of Financial Economics, 80(2), 385-417.

Voordeckers, W., Van Gils, A., \& Van den Heuvel, J. (2007). Board composition in small and medium-sized family firms. Journal of Small Business Management, 45(1), 137-156.

Wang, D. (2006). Founding family ownership and earnings quality. Journal of Accounting Research, 44(3), 619-656.

Warfield, T. D., Wild, J. J., \& Wild, K. L. (1995). Managerial ownership, accounting choices, and informativeness of earnings. Journal of Accounting and Economics, 20(1), 61-91.

Westhead, P. (2003). Company performance and objectives reported by first and multi-generation family companies: a research note. Journal of Small Business and Enterprise Development, 10(1), 93-105.

Xie, B., Davidson III, W. N., \& DaDalt, P. J. (2003). Earnings management and corporate governance: the role of the board and the audit committee. Journal of Corporate Finance, 9(3), 295-316.

Yeo, G. H., Tan, P. M., Ho, K. W., \& Chen, S. S. (2002). Corporate ownership structure and the informativeness of earnings. Journal of Business Finance \& Accounting, 29(7-8), 1023-1046. 